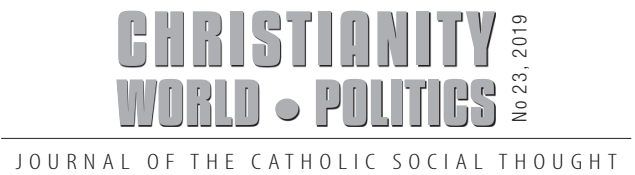

Chantal Delsol

Université Paris-Est Marne-la-Vallée, France

\title{
O nadziei
}

\section{On Hope}

\begin{abstract}
Despite the differences in the explanation of mythical origins of the world, in all cultures up to Judaism and Christianity, the same circular concept of time was inbuilt. Judaism, and Christianity after it, replace it with a linear vision. The future, therefore, is not just a repetition of the past, but a promise of fulfillment. Enlightenment, secularizing the hope of salvation, transforms hope into faith in progress and fulfillment within this world. However, the Messianic promises could not be fulfilled in the dimension of temporality due to the mere accumulation of the produced goods. This approach results therefore in disappointment and in an attempt to find consolation in the enjoyment of the present moment, which should free man from the risk and uncertainty. The opposite of hope is not despair but certainty. True hope demands anthropology of risk and finitude. Only "crazy expectations" (Kierkegaard) and the belief that in the situation of disappointment can come unexpected answers, give life a taste of adventure and a sense of happiness "despite everything".
\end{abstract}

Keywords: hope, culture, Christianity

Abstrakt: Mimo różnic w tłumaczeniu mitycznych początków świata, we wszystkich kulturach aż do judaizmu i chrześcijaństwa przyjmowano taką samą kolistą koncepcję czasu. Judaizm, a za nim chrześcijaństwo, zastępują ją wizją linearną. Przyszłość zatem nie jest jedynie powtórzeniem przeszłości, ale obietnicą spełnienia. Oświecenie, sekularyzując nadzieję na zbawienie, przemienia ją w wiarę w postęp, w spełnienie w ramach tego świata. Mesjanistyczne obietnice nie mogły jednak być spełnione w wymiarze doczesności, za sprawą zwykłej akumulacji wytwarzanych dóbr. Efektem tego podejścia jest zatem rozczarowanie i próba znalezienia pociechy w czerpaniu przyjemności z bieżącej chwili, uwalniającej człowieka od ryzyka i niepewności. Przeciwieństwem nadziei nie jest rozpacz, ale pewność. Prawdziwa nadzieja domaga się antropologii ryzyka i skończoności. Tylko „szalone nadzieje” (Kierkegaard) i przekonanie, że w sytuacji rozpaczy mogą nadejść nieoczekiwane odpowiedzi, nadają życiu smak przygody i poczucie szczęścia „pomimo wszystko”.

Słowa kluczowe: nadzieja, kultura, chrześcijaństwo 
Każda kultura zawiera kosmogoniczne mity, tłumaczące genezę i sens wszechświata. Wszystkie jednak kultury, także zachodnia, aż do momentu pojawienia się judaizmu i chrześcijaństwa, nadają czasowi formę cykliczną. Żydowski monoteizm ugruntował w cywilizacji europejskiej linearną wizję czasu. Jahwe, jedyny i wszechmocny, kieruje historią ludzi i prowadzi ją do chwalebnego wypełnienia. Chrześcijaństwo wzmacnia to przekonanie. Śmierć i zmartwychwstanie Chrystusa otwierają historię. Pojawienie się Boga w czasie łączy czas z wiecznością, przełamując jego cykliczność. Chrystus, jak mówi św. Augustyn, umarł i zmartwychwstał tylko raz. To leżące u podstaw chrześcijańskiej wiary wydarzenie kończy przymus powtarzania.

Czas linearny zakłada możliwość poprawy ludzkiego świata wraz z upływającą historią. Sugeruje, że istnieje nadzieja, czy też nadzieje. Wywołuje pojawienie się wiary w postęp. W tym sensie jest głównym bodźcem intensywnego rozwoju Zachodu. Pojawienie się czasu linearnego prowadzi do ukształtowania się społeczeństw, które trwają w oczekiwaniu na coś nowego. Czas przed nimi jest pełen obietnicy. Obietnice te różnią się w przypadku konkretnych społeczeństw. Czas linearny pozwala bowiem na wiele typów oczekiwań oraz kroków zmierzających ku osiągnięciu tego, co lepsze. W artykule tym pokażemy jak każdy z nich ulega obecnie wyczerpaniu, a jego znaczenie zniszczeniu.

\section{Nowoczesny postęp}

W epoce oświecenia oczekiwanie zbawienia zostaje poddane sekularyzacji i przekształcone $\mathrm{w}$ wizję postępu. Linearny czas idzie tym samym śladem, ale od teraz, pod nieobecność pierwiastka transcendentnego, przypisuje swoje cele immanentnemu światu. Wierzy się w materialny i moralny postęp. Oczekuje szczęścia, a nawet szczęścia absolutnego na ziemi (Condorcet).

Ideologia postępu nie jest wynalazkiem nowoczesności, ale substytutem utraconego chrześcijańskiego ubogacenia, „zamiennikiem” ratującym czas linearny. Zostaje on jednak przekształcony, zarówno dlatego iż osadzony jest wyłącznie na immanencji, jak i dlatego, że naznaczony jest niecierpliwością - obietnice doczesne nie mogą przyjmować zbyt długiego okresu realizacji (te dwie cechy są ze sobą powiązane). 
Teorie postępu są dobrze znane. Od siedemnastego do początków dwudziestego wieku piszą o nich niezliczeni autorzy. Potężny przypływ nadziei ożywia zachodni świat. Wszędzie, ze świętą gorliwością, czegoś się oczekuje. Udoskonalenia mogą lub nie pojawiać się za sprawą wybuchu zwanego rewolucją, które to określenie zostało pozbawione swojego pierwotnego sensu oznaczającego ruch po kole, i zaczęło oznaczać gwałtowny skok naprzód.

\section{Rozczarowanie nowoczesnym postępem}

Idea linearnego czasu zawsze opierała się na wierze i nadziei. Po usunięciu monoteistycznej wiary, nowoczesny postęp początkowo wiązano z rozwojem techniki. W efekcie sekularyzacji, poprawa świata rozumiana jest w kategoriach ilościowych: akumulacji towarów służących zapewnieniu komfortu i dobrego samopoczucia, wzrostu równości, czy wreszcie akumulacji szczęścia. Doczesna idea postępu domaga się zaprowadzania coraz większej równości, coraz większej indywidualnej wolności oraz znoszenia coraz większej ilości zakazów. Podczas, gdy w wizji transcendentnej oczekiwano na owoce będące efektem jakiegoś sposobu ludzkiego postępowania (jakiejś postawy), tutaj postęp wiąże się jedynie z akumulacją wytworów działania, które same traktowane są jako wartości.

Dość szybko okazuje się, że cele, które ma się osiągnąć za sprawą postępu (równość, wolność) nie mogą wzrastać w nieskończoność. Bądź też, jeśli kto woli, że szczęście nie wynika $\mathrm{z}$ akumulacji, ale z osiągniętej równowagi.

Charakterystyczny dla współczesnych czasów brak nadziei oznacza pustkę w podwójnym znaczeniu. Nadzieja zanika niejako na obu „końcach” przemijającej chwili. Zarzuciwszy mesjanistyczne oczekiwania, charakterystyczna dla oświecenia wiara w nieskończony postęp, blaknie.

\section{Brak nadziei}

Kult przyszłości wielkie chwile ma już za sobą. Ogromne rozczarowanie jakie pozostało po nim pozbawia nas nadziei: „Mówisz: Chodźmy! A ja ci odpowiadam: Nie ma dokąd iść...” Zamknięte drzwi nadziei nie otwierają się na hasło projektów, które od długiego czasu sobie przyswajaliśmy. Walka na przekonania została zastąpiona przez spór odnośnie do tożsamości indywidualnej czy grupowej. Oznacza to zasadniczą zmianę perspektywy. Wzrok, wcześniej zakorzeniony w przeszłości i spoglądający w przyszłość, dzisiaj skierowany jest do wewnątrz jednostki czy grupy. Obietnic nie dotrzymano, gdyż były niemożliwe do spełnienia. 
Stąd stwierdzenie, że jedynie mądrość może poradzić sobie ze światem nadziei. Współczesny renesans myśli zbliżonych do stoicyzmu pokazuje, że doświadczamy niepokoju, który jednak towarzyszył człowiekowi także w innych okresach historii.

Kwestia nadziei jest podstawowym węzłem europejskiej kultury. Podsumowuje czas arogancji, postępu, nieskończonego odkrywania tajemnicy istnienia. Introwersja, skierowanie spojrzenia ku sobie, dopatrywanie się w sobie samym źródła, jest dla tej kultury zabójcze. Jednak zaburzenia umysłu, nawet jeśli czynią przyszłość absurdalną, nie przeszkadzają zaistnieć przyszłości. Świat nadal się obraca, tyle, że kręci się wokół własnej osi. Czas linearny, zapełniony obietnicami, ustępuje miejsca niekończącym się powtórkom ubóstwa, wojen i ucisku. I tak bez końca.

\section{Czas cykliczny a ciężar teraźniejszości}

Niezadowolenie z czasu linearnego przenosi nas z powrotem ku wizji czasu cyklicznego, charakterystycznego dla przedchrześcijańskiego okresu, jak również dla wielu współczesnych kultur. „Pomyśl, dla własnej nauki - pisze Marek Aureliusz - o czasach Wespazjana, a zobaczysz, że ludzie żenili się, wychowywali dzieci, chorowali, umierali, walczyli z sobą, urządzali uroczystości, handlowali, uprawiali rolę, schlebiali, byli zarozumiali, podejrzewali, knuli spiski, niektórzy błagali o śmierć, narzekali z powodu losu, kochali się, zbierali skarby, pożądali konsulatów i tronu. Owo to ich życie już nigdzie nie istnieje. Znowu przejdź do czasów Trajana. I tam to samo, i owo życie znikło. Tak samo popatrz na inne nagrobki wszystkich czasów i ludów i zobacz, ilu to zmarłszy w krótkim czasie upadło i rozłożyło się w pierwiastki" (Rozmyślania, IV, 32). Widząc to, co dzieje się teraz, widzimy wszystko, co się wydarzyło od początku czasu, wszystko, co wydarzy się aż po kres czasów; ponieważ wszystko jest takie samo, w ogólności i w szczególe. Jak można nie widzieć tutaj analogii do współczesnego dyskursu, tkwiącego w powtarzalności obaw i nieszczęść?

\section{Idea przeznaczenia zastępuje ideę zbawienia}

Mędrzec musi uwolnić się od nostalgii za przeszłością i od obaw przed przyszłością, gdyż pobawione są one fundamentu w rzeczywistości. Mędrzec jest w pełni zaangażowany w bieżące działanie. Stąd porównanie człowieka do aktora odgrywającego rolę w teatrze: gorliwie angażującego się w realizację aktualnego zadania, bez myślenia o przeszłości i bez troski o przyszłość; jak gdyby obecny akt był jedyną rzeczywistością godną jego uwagi. Człowiek taki nie ma nadziei na nic. Ma tylko swoją mądrość i swoje pogodzenie się ze światem. Tak rozumiane życie mędrca, zanurzone w teraźniejszości, jest poniekąd odwrotnością życia chrześcijanina, wypełnionego 
tragicznym poczuciem istnienia; życia, dla którego liczy się tylko ów dramat istnienia.

Nawoływania stoickiego mędrca, by szukać szczęścia w dowartościowaniu chwili obecnej, a za iluzję uznać pragnienie trwałości czy wręcz wieczności, znajduje ogromny rezonans wśród wielu współczesnych moralistów „po pierwszym łyku piwa”. Przykładem takiej postawy jest potrzeba znalezienia natychmiastowego uznania, błyszczenia w mediach. Ale także skłonność naszych rządów (które nigdy nie odzwierciedlają poglądów ludzi) do konsumowania z wyprzedzeniem owoców przyszłości (poprzez nadmierne zadłużenie, repartycyjne systemy emerytalne, finansowe bańki).

Perspektywa długiego trwania, obecnie całkowicie lekceważona, przypomina nam, że jesteśmy śmiertelni. Dzisiaj zaś nie mamy żadnej odpowiedzi na niepokój związany z tym faktem. Sprowadzenie szczęścia do poczucia satysfakcji z bieżącej chwili stanowi radykalne wyzwanie dla zachodniego prometeizmu. Nieświadomie porzucamy tysiącletnią wizję czasu ponadczasowego, aby powrócić do czasu cyklicznego, który cechuje wszystkie cywilizacje.

\section{Stąd nadzieja jako pytanie}

Nadzieja jest systematycznie odrzucana (w obecnym stanie rzeczy jest ona tchórzostwem, jak pisze Anders). Nie ma nadziei, bo nie ma przyszłości. Zamiast tego pojawia się czas spodziewania się różnych drobnych rzeczy. Brak nadziei, tzn. rozpacz, to powszechny sposób istnienia. Wielkie opowieści oparte na spodziewaniu się zostały zastąpione przez opowieść o końca świata wraz z jego „heurystyką strachu” (H. Jonas).

Współczesną pokusą jest mądrość. Można ją znaleźć wszędzie: od prac wybitnych filozofów (A. Comte-Sponville, J.-L. Nancy) po artykuły w mediach (Paulo Coelho, Marc Levy), jednym słowem wszędzie. Moim zdaniem mądrość to rodzaj psychologicznego więzienia. Religia była krytykowana jako opium dla mas. Mądrość jest takim opium, pocieszeniem dla tego, kto szuka szczęścia, a nie prawdy. Chrześcijaństwo szuka prawdy wbrew wszystkiemu. Głupotą jest, jak mówił św. Paweł, przeciwstawianie szaleństwa Krzyża mądrości stoików. Mądrość jest dzisiaj jednym ze sposobów na porzucenie nadziei. Strzeżmy się współczesnej mądrości.

Jak znaleźć nadzieję? Myślę, że nie powinniśmy próbować odnawiać nadziei związanej z ideą postępu. Idea postępu zastąpiła wiarę w zbawienie, ale to nie jest nadzieja. Idea postępu to myśl o banku przechowującym nasze oszczędności 
(C. Peguy), obraz ze świata burżuazji, w którym wszystko jest liczone, mierzone i ważone. Postęp nie odbywa się całkiem bezinteresownie, ale jest on ważny tylko wówczas, gdy jest wpisany w nadzieję na wieczne zbawienie. W przeciwnym razie jest kurczakiem biegającym bez głowy. Chodzi mi o to, że nadzieja może być tylko duchowa, zaś poza oczekiwaniem na duchowe zbawienie nie ma żadnej nadziei (większość ludzi radzi sobie bez niej, za sprawą mądrości).

Nie chodzi jednak o to, by powiedzieć: wierz w Boga albo pogrążaj się w rozpacz! Nadzieja tworzy się w pewnej atmosferze, w ukrytym świecie stanowiącym swoisty krajobraz wiary. I to chciałabym tutaj opisać.

Nadzieja oznacza wiarę w ludzkie możliwości. Ale także wiarę w możliwości nieskończoności. We „Fragmentach raju”, Giono napisał: „Nie wierzę, że radości tego świata są wszystkie oznaczone w katalogu, do którego przywykliśmy się zwracać w każdym przypadku”. Postęp jest starym gratem, nadzieja jest wiecznie młoda, zawsze pojawia się o świcie. (Czas linearny narodził się z religijnej wiary i nadziei na raj. Wiara i nadzieja, obydwie nie dają się udowodnić. Ponieważ czas linearny obecnie nie odwołuje się już do religijnej wiary, lecz do oczekiwania konkretnego jutra w ramach tego świata, stał się zakładnikiem zdolności świata do samo-tworzenia, do demonstrowania swojego istnienia).

Immanentny czas nie przetrwał kataklizmów dwóch wojen światowych, upadku realnego socjalizmu i „wspaniałego trzydziestolecia”. Wiążąc nadzieję ze spełnieniem poprzez produkcję, został zniszczony. Nie tylko dlatego, że świat, jaki próbowano „wyprodukować” stał się niemożliwy do ogarnięcia. Stało się tak ponieważ nadzieja żywi się impetem, niedokończeniem. Musi być w świecie pewna doza nieracjonalności, nawet jeśli nie chce się mówić wprost o pierwiastku duchowym w szerokim znaczeniu.

Nadzieja jest częścią antropologii ryzyka i skończoności. W świecie, gdzie ludzie starają się przewidzieć wszystko, nie istnieje nadzieja, a jedynie kalkulacja. Przeciwieństwem nadziei nie jest rozpacz, lecz pewność. Postmodernistyczny człowiek nie pragnie nadziei, lecz pewności. Nie akceptuje niepewności. I dzieje się tak we wszystkich obszarach życia: panika towarzysząca ryzyku codziennego życia, medycyna... W kwestii ostatecznego celu, człowiek także chce poczucia pewności. Dlatego woli afirmować pustkę, dającą pewien rodzaj gwarancji po zaniżonej cenie. 


\section{Postmodernistyczny człowiek nie pragnie możliwego, on tego się obawia}

Peguy mówi, że ogrom pamięci i przyzwyczajeń sprawia, że nadzieja staje się niemożliwa. Opisuje "nieprzepuszczalną” duszę (Note conjointe sur M. Decartes), duszę, która jest kompletna. Jak może ona widzieć i kochać „to co będzie”, skoro jest pełna tego, co jest? Owa kompletność, oznacza śmierć duszy, ponieważ nie jest ona w stanie powitać niczego nowego. Odrzuca odnowę, gdyż jest „duszą wypełnioną po brzegi". Nadzieja, natomiast, przedstawiana przez Peguy jako dziecko jest przeciwieństwem przyzwyczajenia, przeciwieństwem śmierci, gdyż „to nadzieja sprawia, że wszystko może się jeszcze raz rozpocząć”. W gruncie rzeczy, to nadzieja gwarantuje wieczną młodość świata: jest przeciwieństwem wiecznego powrotu tego samego. Dziedzicznym Heraklitem. Ryzykiem. Czekaniem na to, czego nie znamy, przyznaniem, że nie opanowaliśmy jeszcze wszystkiego: tym jest nadzieja.

Dusza jest powiązana zarówno z nadzieją jak i z niepokojem. W „My” Zamiatina jesteśmy świadkami pracy nad formacją duszy głównej postaci, gdyż dusza traktowana jest jak choroba, którą trzeba zwalczyć. Dusza powiązana jest z zachowaniem śladów, wyobraźnią, niepokojem, samoświadomością. Dusza boli, a szczęście polega na braku cierpienia.

Nadzieja odnosi się do celów leżących gdzieś dalej, gdyż człowiek nie może być usatysfakcjonowany jedynie komfortem doczesnego życia. Ale dotyczy także, w samym sercu immanentnego świata, tego szalonego oczekiwania (musimy posłużyć się terminem Kierkegaarda), czy też, posługując się bardziej zobiektywizowanym językiem, przekonania, że istnieje nieoczekiwane wyjście z każdej rozpaczliwej sytuacji, ścieżka w każdej ciemności, rozwiązania aporii, których świat nie pozwala dostrzec. Nadzieja polega na przedkładaniu przygody związanej z poszukiwaniem sensu ponad zwykłe szczęście. To wybór. Nadzieja oznacza „pomimo wszystko". 